Expression of Concern

\title{
Expression of Concern on "Physicochemical Parameters and Bioactive Compounds of Strawberry Tree (Arbutus unedo L.) Honey"
}

\author{
Journal of Chemistry \\ Received 4 April 2018; Accepted 4 April 2018; Published 13 June 2018 \\ Copyright (c) 2018 Journal of Chemistry. This is an open access article distributed under the Creative Commons Attribution \\ License, which permits unrestricted use, distribution, and reproduction in any medium, provided the original work is properly cited.
}

Journal of Chemistry would like to express concern with the article titled "Physicochemical Parameters and Bioactive Compounds of Strawberry Tree (Arbutus unedo L.) Honey" published in Journal of Chemistry in 2015 [1] due to possible errors in the reporting.

The journal received a claim of authorship from the Ph.D. cosupervisor of the first author, which the authors disputed. The claimant provided manuscript drafts that reported results done on honey samples collected in January 2010 from one beekeeper in the Algarve, while the published article reports results done on samples collected from December 2010 to March 2011 from several beekeepers in the Algarve. The data in the published article are nearly identical to those in the drafts provided by the claimant despite describing different samples. The authors acknowledge the drafts are genuine, but say the research was done again on new samples of honey.

Journal of Chemistry asked the Pontificia Universidad Católica de Valparaíso (PUCV) and Universidade do Algarve (University of the Algarve) to investigate. The University of the Algarve's investigation was inconclusive, and the PUCV ended their investigation when the first author left that institution. As neither institutional investigation provided conclusive results, the journal's editors would like to inform readers of possible mistakes in the reported experimental results.

\section{References}

[1] P. A. Ulloa, M. Maia, and A. F. Brigas, "Physicochemical parameters and bioactive compounds of strawberry tree (Arbutus unedo L.) honey," Journal of Chemistry, vol. 2015, Article ID 602792, 10 pages, 2015. 


\title{
Physicochemical Parameters and Bioactive Compounds of Strawberry Tree (Arbutus unedo L.) Honey
}

\author{
Pablo A. Ulloa, ${ }^{1}$ Miguel Maia, ${ }^{2}$ and Amadeu F. Brigas ${ }^{3}$ \\ ${ }^{1}$ Escuela de Alimentos, Facultad de Ciencias Agronómicas y de los Alimentos, Pontificia Universidad Católica de Valparaíso, \\ Avenida Waddington 716, 2360100 Valparaíso, Chile \\ ${ }^{2}$ Apismaia, Beekeeping Service, Estrada Municipal 1221, No. 62, 5000-027 Vila Real, Portugal \\ ${ }^{3}$ Departamento de Quimica e Farmacia, Faculdade de Ciencias e Tecnologia, Universidade do Algarve, CIQA, Campus de Gambelas, \\ 8005-139 Faro, Portugal \\ Correspondence should be addressed to Pablo A. Ulloa; pablo.ulloa.f@gmail.com
}

Received 22 January 2015; Accepted 3 March 2015

Academic Editor: Lu Xu

Copyright (C) 2015 Pablo A. Ulloa et al. This is an open access article distributed under the Creative Commons Attribution License, which permits unrestricted use, distribution, and reproduction in any medium, provided the original work is properly cited.

\begin{abstract}
Botanical origin, physicochemical properties (ash, colour, diastase activity, electrical conductivity (EC), hydroxymethylfurfural (HMF), moisture, optical rotation (OP), $\mathrm{pH}$, reducing sugars, total acidity, total soluble solids, and water activity), bioactive compounds (BC), and antioxidant activity obtained from strawberry tree honey from South Portugal were investigated. Results showed that the pollen analysis and physicochemical parameters were found within to meet international honey specifications. Significant differences $(P<0.05)$ in results of ash content, EC, HMF, OP and colour when were compared with analogous famous Italian honey (Sardinia island). For BC, total phenolic and total flavonoid content were $94.47 \mathrm{mg}$ gallic acid/100 g and $5.33 \mathrm{mg}$ quercetin $/ 100 \mathrm{~g}$, respectively. Concerning Portuguese honey, it was also found that radical scavenging activity (DPPH assay) was $43.46 \%$ and antioxidant activity was $18.85 \mathrm{mg}$ ascorbic acid equivalent $/ 100 \mathrm{~g}$ and $9.92 \mathrm{mg}$ quercetin equivalent/100 g. These results confirmed that Portuguese strawberry tree honey has the highest antioxidant activity, when compared with other kinds of honey. This complete report demonstrates advantages and can help to promote consumption and shown their benefical properties (e.g., antioxidant); which will may increase the commercial value.
\end{abstract}

\section{Introduction}

The strawberry tree (Arbutus unedo L., Ericaceae) is a typical evergreen plant (10-12 meters) that thrives in the Iberian Peninsula and in the Mediterranean Basin, as well as in other regions with hot summers and mild rainy winters; it is native of Greece, Lebanon, Ireland, Turkey, Southern Europe, and the Sardinia island (Italy) [1-3]. In Portugal this species is known as Medronho and is mainly implanted in the south (Algarve) $[4,5]$. Fruits are spherical, have an orange-red colour, and are tasty only when fully ripe. The bitter taste of fruits can be attributed to tannins together with other phenolic compounds. Its fruits are processed into traditional products such as alcoholic beverages, jams, jellies, and marmalades and are also consumed as fresh fruit $[4,5]$. They are known in folk medicine as antiseptic, diuretic, and laxative, while the leaves are used as astringent, diuretic, urinary antiseptic, antidiarrheal, and depurative and, also more recently, in the therapy of hypertension, diabetes, and inflammatory diseases. It has been shown that leaf extract contains several phenolic compounds, like tannins, flavonoids, phenolic glycosides, and $\alpha$-tocopherol [1]. Flowers (resembling hot-air balloons) are produced in clusters (15-30 flowers) on red stems and are bell-shaped, with recurved lobes, white or pink, and nectar-scented. These flowers are significant sources of nectar for bees, which can be used to transform it into honey $[2,4]$.

Honey is a natural substance produced by honeybees (Apis mellifera) from flower nectar or from honeydew and has a high nutritional and prophylactic-medicinal value. It is a source of readily available sugar, organic acids, some amino acids, macro- and microelements, and biologically active compounds that have antibacterial and antioxidant properties. The chemical composition and amount of these 
compounds are influenced by the floral source, climate and environmental conditions, and beekeeper skills [6-10]. Therefore, in every region of the world, the composition of honey is different. The current tendency is to define the differentiating character of honeys from different floral sources in order to obtain a standard of quality while keeping its authenticity, making it market competitive [11].

Floral origin is normally determined by melissopalynological analysis $[12,13]$. Normally, honeys are classified as unifloral, when the pollen frequency of one plant is over $45 \%$ (predominant pollen). In some cases, the botanical classification is carried out in a different manner when the pollen grains are "under- or overrepresented" in relation to the nectar their flowers yield. Strawberry tree honey is considered unifloral when it shows a frequency between 8 and $20 \%$ of pollen grains of $A$. unedo $[14,15]$.

Some of the popular types of honey available in Portugal, including bell heather (Erica spp.), rosemary (Rosmarinus officinalis), sunflower (Helianthus annuus), and orange (Citrus spp.), are of unifloral origin and are high in demand, in sharp contrast to strawberry tree honey, produced in commercial insignificant amounts in Algarve [16]. Very little is known or reported in terms of its physicochemical parameters and bioactive properties, both at local and international levels. Compared to other types of honey, it has a distinct fragrance and bitter aftertaste locally known as "bitter honey" $[17,18]$. The sensory characteristics of bitter honey are easily recognizable: it is amber-colored when liquid and beige-brown when crystallized; the smell is intense, characteristic, ripe, and similar to that of coffee; the taste is slightly sweet initially and decidedly bitter and astringent later $[4,19]$. This kind of honey is also produced in the Sardinia island where it is widely appreciated, with market prices from 4 to 8 times higher than those of common "sweet" honey, probably because it has been shown that it is a good source of bioactive compounds [4, 10, 13]. Also the number of customers that attach a great importance to the origin of food products as an indicator of quality is remarkable [18]. Many consumers seek high quality products with a clear regional identity of the provenance areas; therefore for the apiculture industry it is in their best interest to offer honeys with specific geographical characteristics, bioactive compounds, and superior quality [11].

The strawberry tree honey produced in Portugal appears to have attracted little interest, in comparison with the famous Sardinia honeys. Scientific data for this type of Portuguese honey is rare in the literature; thus the aim of this work is to provide information on the characterization of strawberry tree honey produced in the Algarve. Presumably, with better knowledge of its physicochemical parameters and biological activity, this kind of honey can compete in a specialized market.

\section{Materials and Methods}

2.1. Samples. Strawberry tree (A. unedo L.) honey samples $(n=12)$ were harvested in different areas from South of Portugal (Faro, Cachopo, Ameixial, Martin Longo, and Tavira) directly from local beekeepers; all samples were collected during 2011 season. The analysis of each sample was carried out in triplicate for each test. All samples were obtained by centrifugation, unblended with other honeys, and unpasteurized. Honey samples were stored at room temperature $\left(20 \pm 3^{\circ} \mathrm{C}\right)$ until analysis.

2.2. Melissopalynological Analysis. Honey origin was determined by pollinic analysis after acetolysis [15]. Random sample $(20 \mathrm{~g})$ of honey was dissolved with $40 \mathrm{~mL}$ of distilled water $\left(40^{\circ} \mathrm{C}\right)$, stirred, and then centrifuged for $15 \mathrm{~min}$ at $4640 \mathrm{~g}$ (Kubota, model Kn-70, Japan). The supernatant was removed and mixture with $10 \mathrm{~mL}$ of acetolysis solution $(1 \mathrm{~mL}$ of $\mathrm{H}_{2} \mathrm{SO}_{4}$ to $9 \mathrm{~mL}$ of $\mathrm{C}_{4} \mathrm{H}_{6} \mathrm{O}_{3}$ ) was added to the remaining sediment in each tube. The reaction mixture was placed in a $70^{\circ} \mathrm{C}$ water bath for $10 \mathrm{~min}$. After $10 \mathrm{~min}$ centrifugation at $4176 \mathrm{~g}$, the supernatant was removed and a drop of liquefied Kaiser's glycerol gelatin (Merck, Germany) was added to pollen grains sediment. Finally, the entire mixture was spread on a glass slide over an area of about $20 \times 20 \mathrm{~mm}$. For each sample, at least 800 pollen grains were counted. The pollen grains were grouped by pollinic types and the corresponding data was expressed as percentages.

\subsection{Physicochemical Parameters}

2.3.1. Ash Content. The ash content was determined by placing $5-10 \mathrm{~g}$ of honey sample in a crucible in a muffle furnace for calcination $\left(550^{\circ} \mathrm{C} \times 6 \mathrm{~h}\right)$ until constant weight, with the precaution of including a previous caramelisation step on a heating plate to control the production of foams and sample losses.

2.3.2. Colour by Absorbance. The colour by absorbance was measured in a honey solution of $50 \%(\mathrm{w} / \mathrm{v})$ at $635 \mathrm{~nm}$, in a double beam UV/Vis spectrophotometer (Hitachi U-2000, Tokyo, Japan) according to Ferreira et al. [8] and Aazza et al. [20]; before measurements all sugar crystals were dissolved. Honey samples were classified according to the Pfund scale [21], after conversion of the absorbance values $\left(A_{635}\right)$, using

$$
(\mathrm{mm} \text { Pfund })=-38.70+\left(371.39 \cdot A_{635}\right) \text {. }
$$

2.3.3. Diastase Activity (DA). The DA was measured using the Phadebas amylase test tablets purchased from Magle (Lund, Sweden), according to the International Honey Commission [22]. DA was referred to as diastase number (DN) in the Schade scale, which corresponds to the Gothe scale number, or to $g$ of hydrolyzed starch per hour at $40^{\circ} \mathrm{C}$, per $100 \mathrm{~g}$ of honey.

2.3.4. Electrical Conductivity (EC). The electrical conductivity of honey samples was measured at $20^{\circ} \mathrm{C}$ in a $20 \%$ $(\mathrm{w} / \mathrm{w})$ honey solution (dry matter basis) in deionised distilled water using a Crison conductometer 525 (Cataluña, Spain). The results were expressed in millisiemens per centimeter $(\mathrm{mS} / \mathrm{cm})$.

2.3.5. Hydroxymethylfurfural (HMF) Content. The HPLC method used was based on the method recommended by 
the International Honey Commission [22]. Briefly, the honey samples $(5 \mathrm{~g})$ were diluted to $50 \mathrm{~mL}$ with Milli-Q water filtered using a $0.45 \mu \mathrm{m}$ nylon membrane filter (Merck, Germany) and $20 \mu \mathrm{L}$ injected into an HPLC system (JASCO, LG-1580-04 with PU-2080 plus Intelligent HPLC pump) equipped with a Photodiode Array Detector (JASCO, MD2015 Plus Multiwavelength Detector). HPLC column was a Merck Purospher Star RP-18e, $5 \mu \mathrm{m}$ (Merck, Germany). The HPLC included an isocratic mobile phase, $90 \%$ water, and $10 \%$ methanol (Fisher Scientific, UK) at a flow rate of $0.7 \mathrm{~mL} / \mathrm{min}$. All solvents used were of HPLC grade. The detection wavelength was $285 \mathrm{~nm}$. HMF content of the sample was calculated by comparing the corresponding peak area of the sample and those of the standard solutions (concentration range of $2.5 \mu \mathrm{g} / \mathrm{mL}$ to $60 \mu \mathrm{g} / \mathrm{mL}$ ) of HMF $\left(\mathrm{C}_{6} \mathrm{H}_{6} \mathrm{O}_{3}\right.$, Sigma-Aldrich, Germany) after correcting for the honey dilution. There was a linear relationship $\left(R^{2}=0.9993\right)$ between the concentration and the area of the HMF peak (results were calculated as the mean of three values and expressed as $\mathrm{mg} / \mathrm{kg}$ ).

2.3.6. Moisture Content (MC). Moisture content in honey was determined using a refractometer (Atago 1T Abbe Refractometer, Tokyo, Japan). The refractive indices of honey samples were measured at room temperature and the readings were further corrected for temperature using a factor of $0.00023 /{ }^{\circ} \mathrm{C}$. Percentage of moisture content values corresponding to the corrected refractive index values was calculated using the revised and updated Chataway table [23].

2.3.7. Optical Rotation (OR). Honey OR was measured polarimetrically using the method recommended by the International Honey Commission [22]. Approximately $12 \mathrm{~g}$ of honey sample (corresponding to about $10 \mathrm{~g}$ of dry substance $/ 100 \mathrm{~mL}$ ) was clarified first with Carrez I reagent $(10 \mathrm{~mL}$, for $30 \mathrm{~s})$ and then with Carrez II $(10 \mathrm{~mL}$, for $30 \mathrm{~s})$. Distilled water was then added to a final volume of $100 \mathrm{~mL}$ and left for $24 \mathrm{~h}$. The solution was filtered and read out in an Atago Polax-D polarimeter (Tokyo, Japan). The optical rotation $\left(\alpha_{D}^{20}\right)$, expressed as the angle of rotation of the polarized light at the wavelength of the sodium $D$ line $(\lambda=$ $589.3 \mathrm{~nm}$ ) at $20^{\circ} \mathrm{C}$, was calculated using

$$
\left(\alpha_{D}^{20}\right)=\left[\frac{(\alpha \cdot 100)}{(L \cdot p)}\right],
$$

where $\left(\alpha_{D}^{20}\right)=$ angular rotation determined, $L=$ length in decimeters of the polimeter tube, and $p=$ mass, expressed as grams of dry honey.

2.3.8. $p H$. Honey $\mathrm{pH}$ was measured, in a solution prepared with $5 \mathrm{~g}$ of honey in $25 \mathrm{~mL}$ of $\mathrm{CO}_{2}$-free distilled water using the method recommended by International Honey Commission [22], using a pH-meter Crison (micropH 2001, Cataluña, Spain). Prior to measurements, the instrument was calibrated with standard buffer solutions of $\mathrm{pH} 7$ and $\mathrm{pH} 4$.

2.3.9. Reducing Sugars. Reducing sugars were determined using 3,5-dinitrosalicylic acid (DNSA). A $1 \mathrm{~mL}$ of the honey solution $(1 \mathrm{mg} / \mathrm{mL})$ was mixed with an equal amount of DNSA solution and incubated in a boiling water bath for $10 \mathrm{~min}$ [24]. The mixture was allowed to cool to ambient temperature and was mixed with $7.5 \mathrm{~mL}$ of distilled water and the absorbance was measured at $540 \mathrm{~nm}$ using a UVVis spectrophotometer (Hitachi U-2000, Tokyo, Japan). A standard glucose stock solution, within the range of 200 to $1000 \mu \mathrm{g} / \mathrm{mL}\left(R^{2}=0.9945\right)$, was used as a standard curve and the mean results were expressed as ( $\mathrm{mg} / 100 \mathrm{~g}$ of honey).

2.3.10. Total Acidity. The total acidity of honey samples was determined using the method recommended by International Honey Commission [22]. Results were expressed as meq $/ \mathrm{kg}$.

2.3.11. Total Soluble Solids (TSS). Total soluble solids of the honey samples were determined by refractometry using an Abbe Atago 1T (Tokyo, Japan) and results were expressed in ${ }^{\circ}$ Brix. All measurements were performed at room temperature and the readings were corrected for a reference temperature of $20^{\circ} \mathrm{C}$ by adding the correction factor of $0.00023 /{ }^{\circ} \mathrm{C}$.

2.3.12. Water Activity $\left(a_{w}\right)$. Honey samples were placed inside the sample-holder and used for determination of $a_{w}$ using a water activity meter Rotronic Hygrolab 3 (Rotronic AG, Bassersdorf, Switzerland), equipped with a temperaturecontrolled system; measurements were performed at a temperature of $25^{\circ} \mathrm{C}$ and water activity of the samples was based on its equilibrium relative humidity (ERH, \%). $a_{w}$ and ERH were calculated as follows:

$$
a_{w}=\left(\frac{\mathrm{ERH}}{100}\right) .
$$

\subsection{Bioactive Compounds}

2.4.1. Total Phenolic Content (TPC). TPC was determined spectrophotometrically using the Folin-Ciocalteu Method (FCM) according to Alves et al. [16] and Özcan and Ölmez [25], with some modifications. Approximately $5 \mathrm{~g}$ of honey was treated with $50 \mathrm{~mL}$ of distilled water, and the resulting solution was filtered using a qualitative filter paper. The filtered solution $(0.5 \mathrm{~mL})$ was mixed for $5 \mathrm{~min}$, with $2.5 \mathrm{~mL}$ Folin-Ciocalteu's phenol reagent $0.2 \mathrm{~N}$ (Sigma-Aldrich, Germany), and then $2 \mathrm{~mL}$ of a $75 \mathrm{~g} / \mathrm{L} \mathrm{Na} \mathrm{CO}_{3}$ solution was added. Samples were incubated in the dark, at room temperature $(2 \mathrm{~h})$, and their absorbance was read at $760 \mathrm{~nm}$ in a UV/Vis double beam spectrophotometer Hitachi U-2000 (Tokyo, Japan). The blank solution consisted of methanol. The TPC was determined from a standard curve prepared using standard solutions, within the range of 5 to $150 \mu \mathrm{g} / \mathrm{mL}\left(R^{2}=\right.$ $0.9941)$. The mean of three readings was used, expressed as $\mathrm{mg}$ of gallic acid equivalents (GAE)/100 $\mathrm{g}$ of honey.

2.4.2. Total Flavonoid Content (TFC). TFC was determined according to Alvarez-Suarez et al. [26] and Shantal Rodriguez Flores et al. [27] with some modifications. Approximately $1 \mathrm{~g}$ of honey sample was dissolved in methanol to obtain a final concentration of $0.04 \mathrm{~g} / \mathrm{mL}$. Then $5 \mathrm{~mL}$ of each solution was 
mixed with $5 \mathrm{~mL}$ of $2 \% \mathrm{AlCl}_{3}$. The mixture was left in the dark for $10 \mathrm{~min}$, at room temperature. The absorbance was measured at a wavelength of $415 \mathrm{~nm}$ using a Hitachi U-2000 double beam UV/Vis spectrophotometer (Tokyo, Japan). The blank sample consisted of $5 \mathrm{~mL}$ honey solution with $5 \mathrm{~mL}$ methanol without $\mathrm{AlCl}_{3}$ (Merck, Germany). The TFC was determined from a standard curve prepared using standard solutions, within the range of 2 to $50 \mu \mathrm{g} / \mathrm{mL}\left(R^{2}=0.9927\right)$. The mean of three readings was used, expressed as $\mathrm{mg}$ of quercetin equivalents (QE)/100 g of honey.

2.4.3. Radical Scavenging Activity. The scavenging activity of honey samples for 2,2-diphenyl-2-picrylhydrazyl (DPPH) was measured as described by Alvarez-Suarez et al. [26] and Alves et al. [16], with some modifications. Honey samples were dissolved in methanol with a final concentration of $1 \mathrm{mg} / \mathrm{mL}$. Briefly, $0.75 \mathrm{~mL}$ of each sample solution was mixed with $1.5 \mathrm{~mL}$ of DPPH (Sigma-Aldrich, Germany) in methanol $(0.039 \mathrm{mg} / \mathrm{mL})$; all mixtures were left for $25 \mathrm{~min}$ at room temperature in the dark; after this the absorbance was read at $517 \mathrm{~nm}\left(\mathrm{Abs}_{H}\right)$ using a Hitachi U-2000 double beam UV/Vis spectrophotometer (Tokyo, Japan). The blank sample consisted of $0.75 \mathrm{~mL}$ of methanol to which $1.5 \mathrm{~mL}$ of DPPH was added $\left(\mathrm{Abs}_{B}\right)$. Ascorbic acid was used as a positive control $(5-70 \mu \mathrm{g} / \mathrm{L})$. The radical scavenging activity was calculated as follows:

$$
\text { \%Inhibition }=\left[\frac{\left(\mathrm{Abs}_{B}-\mathrm{Abs}_{H}\right)}{\mathrm{Abs}_{B}}\right] \cdot 100 .
$$

2.4.4. Antioxidant Capacity. The antioxidant capacity was evaluated as described by Meda et al. [28]. Approximately $1 \mathrm{~g}$ of honey samples was dissolved in methanol to obtain a final concentration of $0.04 \mathrm{mg} / \mathrm{mL}$. Then $0.75 \mathrm{~mL}$ of each solution was mixed with 1.5 of a $0.05 \mathrm{mg} / \mathrm{mL} \mathrm{DPPH}$ solution in methanol. The mixture was left in the dark for $15 \mathrm{~min}$ at room temperature. Absorbance was measured at $517 \mathrm{~nm}$ using a Hitachi U-2000 double beam UV/Vis spectrophotometer (Tokyo, Japan). The blank sample consisted of $0.75 \mathrm{~mL}$ of a honey solution with $1.5 \mathrm{~mL}$ of methanol. Antioxidant content was determined from a standard curve prepared using standard solutions, within the range of 2 to $12 \mu \mathrm{g} / \mathrm{mL},\left(R^{2}=\right.$ 0.9948 ) for ascorbic acid and for quercetin of 1 to $8 \mu \mathrm{g} / \mathrm{mL}$ $\left(R^{2}=0.9899\right)$. The mean of three values was calculated and expressed as mg of ascorbic acid equivalent antioxidant content $(\mathrm{AEAC}) / 100 \mathrm{~g}$ of honey and $\mathrm{mg}$ of quercetin equivalent antioxidant content (QEAC)/100 g of honey.

2.4.5. Statistical Analysis. Data analysis for the results obtained for strawberry tree honey samples of all parameters (physicochemical and bioactive compounds) was carried out employing Statgraphics Centurion XV (StatPoint, Virginia, USA) using analysis of variance (ANOVA) and Student's $t$ test was used to examine differences between Portuguese and Italian honeys. Results were expressed as a mean value $(x)$ and standard deviation (SD). Differences were considered significant at a level of $P<0.05$.

\section{Results and Discussions}

3.1. Pollen Analysis. Results of microscopic analysis of the analyzed honey samples were summarized in Figure 1. Thirtyone pollen types were found in the honey samples studied. Pollen from Echium plantagineum, Ceratonia siliqua, Cistaceae, Arbutus unedo, Lavandula stoechas, Reseda luteola, and Citrus spp. types was present in all honey samples (86\%). Arbutus unedo was the predominant pollen in all samples (Figure 2), accounting for more than $20 \%$ of the pollen. Von Der Ohe et al. [15] established that, for a honey to be considered a strawberry tree classified as unifloral, this sample must show a range of pollen grains between 8 and $20 \%$ of this type of flower (lower pollen content underrepresented and percentages of pollen grains < 45\%) $[13,17,29]$. All samples correspond to unifloral of $A$. unedo honey (mean pollen content of $31.96 \%$ ). Similar results were obtained by Tuberoso et al. $[4,18]$ for Italian honey samples with a mean value of $37.6 \%$ pollen content and range from $14 \%$ to $65 \%$, respectively.

3.2. Physicochemical Parameters. Table 1 shows results obtained for each physicochemical parameter analyzed ( $x \pm \mathrm{SD}$, range). All honey samples exhibit values within the ones established by several regulations [23,30], except for diastase activity (>8 Gothe degrees), but this value is close to Italian and Portuguese honeys, which indicates that this value results from an intrinsic characteristic of this type of honey (A. unedo).

Ash content for analyzed honey samples shows a mean value of $0.582 \%$ and electrical conductivity (EC) mean value was $0.643 \mathrm{mS} / \mathrm{cm}$ (Table 1). Similar results were found by Alves et al. [16] when analyzing strawberry tree honey with EC value of $0.65 \mathrm{mS} / \mathrm{cm}$; those samples were obtained from Faro (South Portugal). Compared to the results obtained by Aazza et al. [20] for strwaberry tree commercial honey for the value of ash content $(0.70 \%)$ and $\mathrm{EC}(0.88 \mathrm{mS} / \mathrm{cm})$, this study showed significant differences $(P<0.05)$. Oddo et al. [31] showed values were $0.32 \%$ and $0.74 \mathrm{mS} / \mathrm{cm}$, respectively, for Italian honey. Generally, the ash content of nectar honey is $\leq 0.6 \%$ whereas for honey or blends of honeydew this value is $\geq 1.2 \%$. On the other hand, the EC for nectar honey is $\leq 0.8 \mathrm{mS} / \mathrm{cm}$ and for honeydew $\geq 0.8 \mathrm{mS} / \mathrm{cm}[23,30]$. The $\mathrm{EC}$ of honey is due to the presence of minerals, organic acids, protein, and sugar composition and is a good tool to distinguish between floral and honeydew honey, according to present standards [24, 32]. Some nectar honeys, for example, strawberry tree (A. unedo), bell heather (Erica), eucalyptus (Eucaliptus), lime (Tila spp.), ling heather (Calluna vulgaris), manuka (Leptospermum), and tea tree (Melaleuca spp.), can show higher values of EC which are accepted by current legislations $[22,23,30]$. These two parameters show a linear relationship, with increased ash contents being accompanied by an increase of EC (our study was $R^{2}=0.740$ ) [20, 33, 34]. Ash content gives a direct measure of the inorganic residue after carbonization, while the electrical conductivity measures all ionizable organic and inorganic substances [14, 33, 35]. Mineral content depends on various factors such as botanical origin, geographical conditions, soil composition, environmental pollution, and extraction techniques [16]. 


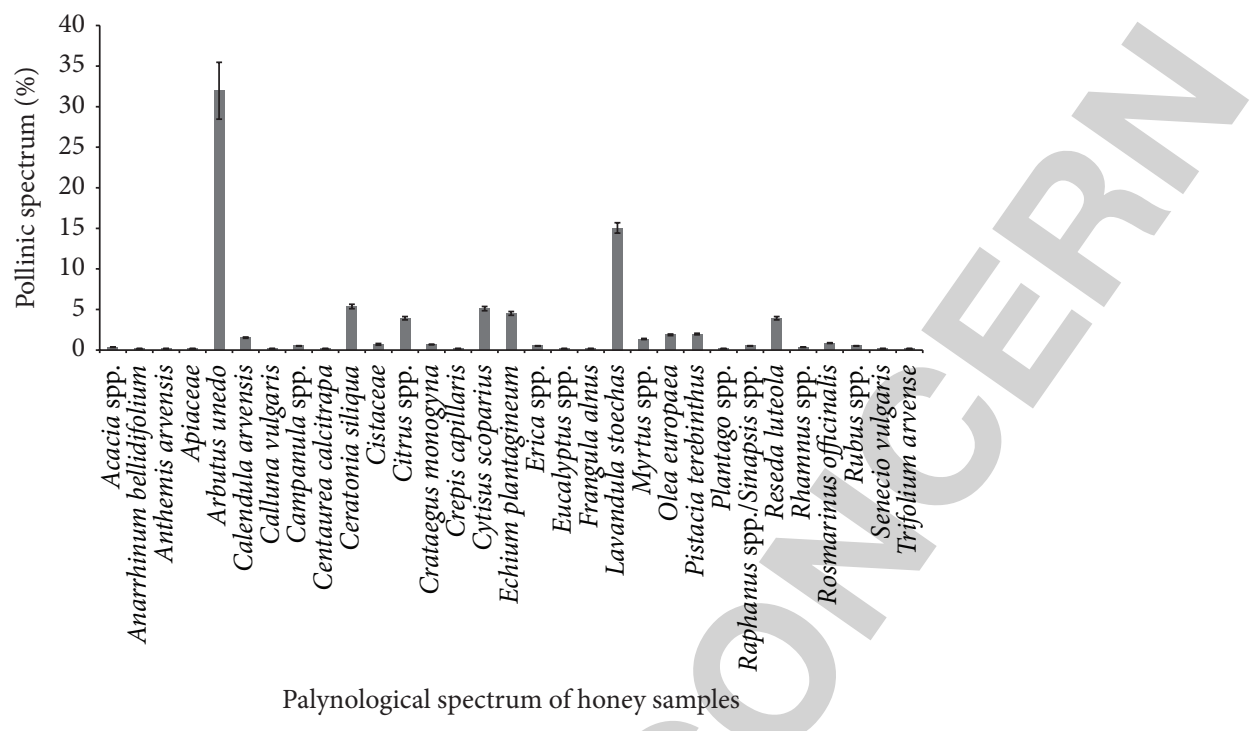

Figure 1: Palynological spectrum of strawberry tree (Arbutus unedo) honey samples.

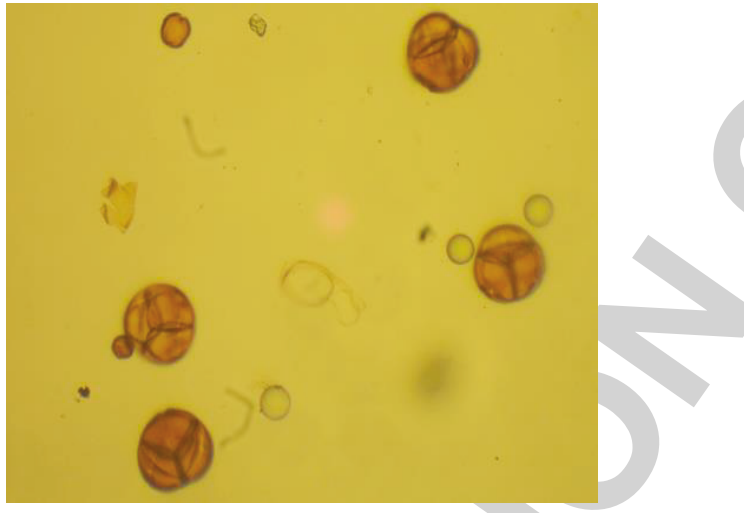

FIGURE 2: Pollen separated from strawberry tree (Arbutus unedo) honey as seen at $40 \mathrm{x}$ obtained after acetolysis to determination of melissopalynology.

The moisture content (MC) for honeys analyzed showed a mean value of $19.87 \%$ (Table 1), close to the limits (but not exceeding 20\%) established by Codex [23] and EU [30]. This parameter is important in terms of shelf-life. For high values of MC it is possible to obtain fermentation by osmophilic yeast, reducing the overall quality of honeys. It also indicates a premature extraction or extraction under high humidity conditions [33]. Similar results were found by Aazza et al. [20] for $A$. unedo commercial honey; these samples showed value of $19.8 \%$. On the other hand, Alves et al. [16] and Oddo et al. [31] found mean moisture content of $18.6 \%$ and $18.9 \%$ for the Portuguese and Italian strawberry tree honeys, respectively. Water content depends on the botanical origin of honey, atmospheric conditions, degree of maturity reached in the hive, season of production, human manipulation, processing techniques, and storage conditions $[1,34]$. In the present study this is probably the result of a slightly wet season since A. unedo blossoms late in the winter (December).
Total soluble solids (TSS) content of the honey samples showed a mean value of $78.35^{\circ}$ Brix (Table 1 ). Variations in the TSS were found to be dependent on climate and floral source amongst other factors, through a strictly linear relationship (our study was $R^{2}=0.925$ ) between moisture content and total soluble solids [35].

For water activity $\left(a_{w}\right)$ of the strawberry tree honey a mean value of 0.652 was found (Table 1 ); normally water activity is within a range of $0.5-0.6[24,34]$. The $a_{w}$ parameter is important in the inhibition of microorganism development and enzyme activity; this is mainly determined by the presence of soluble chemical species (mainly fructose and glucose). Differences between $a_{w}$ values of the different honey types are the result of their diverse sugar composition $[20,36]$. The osmophilic yeasts are only able to grow above minimal water activities of 0.60 and are specialists in surviving under conditions of high sugar concentrations. Saccharomyces spp. are responsible for generating honey fermentation [24].

The mean reducing sugars content in strawberry tree honey was $73.64 \mathrm{mg} / 100 \mathrm{~g}$ of honey (Table 1), and similar results were also found by Oddo et al. [31] for Italian strawberry tree honey with a mean value of $69.3 \mathrm{mg} / 100 \mathrm{~g}$ of honey. Codex [23] and EU [30] standards require the following: reducing sugars in nectar honey must be $\geq 60 \mathrm{~g} / 100 \mathrm{~g}$ of honey, and in honeydew honey this value must be $\geq 45 \mathrm{~g} / 100 \mathrm{~g}$ of honey. Reducing sugars, which include mainly glucose and fructose, are the major constituents of honey [20, 32]. The carbonyl groups of reducing sugars can react with free amino residues from amino acids/proteins generating melanoidin compounds, which are formed at several stages during the Maillard reaction, including Amadori compounds to amino reductoes or reductones and the formation of melanoidin polymers. These compounds have a brown coloration and have been demonstrated to possess a strong antioxidant activity, therefore contributing to a product with more active compounds $[8,9,37]$. 
TABLE 1: Results of the physicochemical parameters of strawberry tree (Arbutus unedo) honey samples.

\begin{tabular}{|c|c|c|c|c|}
\hline Parameters & Range $[\min -\max ]$ & $x \pm \mathrm{SD}$ & Limits values & Reference \\
\hline Ash content $(\%)$ & $0.465-0.640$ & $0.582 \pm 0.103$ & Max 0.6 & {$[17,18]$} \\
\hline Colour (mm Pfund) & $18.49-29.26$ & $23.07 \pm 5.56$ & & \\
\hline $\mathrm{EC}(\mathrm{mS} / \mathrm{cm})$ & $0.628-0.645$ & $0.643 \pm 0.04$ & $\operatorname{Max} 0.8$ & {$[17,18]$} \\
\hline DA (Gothe) & $3.41-3.73$ & $3.58 \pm 0.13$ & Min 8 & {$[17,18]$} \\
\hline $\mathrm{HMF}(\mathrm{mg} / \mathrm{kg})$ & $13.46-17.44$ & $16.11 \pm 2.30$ & $\operatorname{Max} 40$ & {$[17,18]$} \\
\hline Moisture (\%) & $18.19-20.27$ & $19.87 \pm 0.57$ & $\operatorname{Max} 20$ & {$[17,18]$} \\
\hline $\mathrm{OR}(\alpha)_{D}^{20}$ & $-6.37--5.50$ & $-6.06 \pm 0.36$ & & \\
\hline $\mathrm{pH}$ & $4.47-4.57$ & $4.52 \pm 0.05$ & & \\
\hline Reducing sugars (mg/100 g of honey) & $70.84-78.38$ & $73.64 \pm 4.12$ & Min 60 & {$[17,18]$} \\
\hline Total acidity $(\mathrm{meq} / \mathrm{kg})$ & $24.63-29.16$ & $26.76 \pm 2.28$ & $\operatorname{Max} 50$ & {$[17,18]$} \\
\hline TSS $\left({ }^{\circ}\right.$ Brix $)$ & $78.00-79.94$ & $78.35 \pm 0.49$ & & \\
\hline$a_{w}$ & $0.647-0.649$ & $0.652 \pm 0.001$ & & \\
\hline
\end{tabular}

Optical rotation (OR) of all samples presents a laevorotatory behavior (negative values) characteristic of nectar honeys, showing an average value of $-6.06^{\circ}$ (Table 1 , significantly different $P<0.05)$. Normally, honey that shows this kind of OR has a higher fructose content, but the overall optical rotation depends on the concentration of the various sugars present. Similar results were also obtained by Oddo et al. [31], who found similar mean values of $-13^{\circ}$ for Italian strawberry tree honey.

The colour of samples was classified according to their absorbance as white [21], with a mean value of $23.07 \mathrm{~mm}$ Pfund (significantly different $P<0.05$ ), lighter than that of the samples studied by Aazza et al. [20] and Persano Oddo et al. [31], who classified their honeys as amber $(88.9 \mathrm{~mm}$ Pfund) and light amber (70 mm Pfund), respectively. Colour parameters depend on various factors, with their mineral content being an important one. Light honeys usually have low ash contents, while dark honeys generally have higher ash contents $[16,18,34]$. Sometimes the melanoidin compounds (Maillard reaction) concentration, which has a brown colour, also plays an important role in some foods [9].

The $\mathrm{pH}$ of the analyzed honey samples showed a mean value of 4.52 (Table 1). This parameter is of great importance during extraction and storage, since acidity can influence texture, stability, and honey shelf-life [33]. This value was in accordance with the acceptable range for nectar honey (from 3.2 to 4.5); similar results were also obtained by Aazza et al. [20] and Oddo et al. [31] who found that values of $\mathrm{pH}$ were 4.49 and 4.2 , respectively. On the other hand, significant differences $(P<0.05)$ were obtained by Alves et al. [16] who analyzed strawberry tree honey, with $\mathrm{pH}$ mean value of 3.8.

Total acidity of all samples was within the International Legislation $[23,30]$, which required a value of $\leq 50 \mathrm{meq} / \mathrm{kg}$. Honey samples analyzed showed a mean value of $26.76 \mathrm{meq} / \mathrm{kg}$ (Table 1). Italian strawberry tree honey showed a range of values from 27.3 to $53.4 \mathrm{meq} / \mathrm{kg}$ [31]. In comparison between strawberry tree commercial honey (significantly different $P<0.05$ ) shown a mean value of $32.42 \mathrm{meq} / \mathrm{kg}$ [20]. The presence of organic acids, particularly gluconic acids produced from nectar during ripening by glucose oxidase in equilibrium with their lactones or esters, and inorganic ions, such as phosphate and chloride, contributes to the acidity of honey [38]. High acidity can be indicative of fermentation, since yeasts and molds are capable of developing in an acidic environment and do not grow well in alkaline media $[20,35]$. Other factors that influence total acidity are geographical origin and harvest season [16]. The honey produced in South Portugal (Faro particularly) showed high acidity values in comparison with other regions [16].

Diastase activity (DA) and hydroxymethylfurfural (HMF) content are widely recognized as parameters indicating freshness and/or overheating of honey [19, 27, 34, 38]. For DA, samples of honey tested have shown a mean value of 3.58 Gothe degrees (Table 1). This enzymatic activity is much lower than the limits established by International Regulation, which should not be less than 8 Gothe degrees [23, 30]. However, similar results were also obtained by Oddo et al. [31], with the honeys analyzed showing a range of 0 to 9.2 with a mean of 5.2 Gothe degrees. Besides, Aazza et al. [20] found DA mean value 2.25 of strawberry tree commercial honey. Enzymatic activity depends upon geographic and floral origins of the product, as well as on its freshness [34]. Normally, thermal treatment (e.g., pasteurization) decreases diastase activity $[25,38]$.

For the HMF content of the honeys analyzed, an average value of $16.11 \mathrm{mg} / \mathrm{kg}$ was obtained (Table 1). Significant differences $(P<0.05)$ were found in comparison with results obtained by Aazza et al. [20] and Oddo et al. [31], where found the HMF levels for Portuguese and Italian honeys of 8.2 and $4.4 \mathrm{mg} / \mathrm{kg}$, respectively. Portuguese honey showed higher values; this phenomenon can be explained by poor processing practices (e.g., high temperature and wrong storage conditions).

The Codex [23] and EU [30] established the maximum HMF level allowed in honey as $40 \mathrm{mg} / \mathrm{kg}$, with the following exceptions: $80 \mathrm{mg} / \mathrm{kg}$ for honey from countries with tropical temperatures and $15 \mathrm{mg} / \mathrm{kg}$ for honey with a low enzymatic level, respectively. Several factors influence the formation of HMF in honey. These factors may include the use of metallic containers, physicochemical parameters ( $\mathrm{pH}$, total acidity, and mineral content) of honey itself, which are related to the floral source from which the honey has been extracted, 
humidity, and thermal and/or photochemical stress. The HMF formation results from the acid-catalyzed dehydration of hexose sugars, with fructose being particularly susceptible $[19,25,38]$.

Taking into account the results obtained for the above physicochemical parameters, namely, ash content, EC, $\mathrm{pH}$, $\mathrm{OR}$, and reducing sugars, and also melissopalynological analysis, it is clear that all honey samples studied were nectar honeys and unifloral $[22,23,30]$.

3.3. Bioactive Compounds. There is increasing motivation from consumers to acquire products that have interesting health properties $[6,18,39]$. Honey, in that sense, is a very rich product with biological activity attributed to it since ancient times. Table 2 shows the results obtained for the total phenolic content (TPC), total flavonoid content (TFC), radical scavenging activity, and antioxidant activity of strawberry tree honey samples using DPPH assays.

This kind of honey has shown a high amount of TPC, $94.47 \mathrm{mg}$ of GAE/100 $\mathrm{g}$ of honey (Table 2), very close to the values observed in the Italian honey samples of the same type [10] which was $97.2 \mathrm{mg}$ of GAE/100 $\mathrm{g}$ of honey. Besides, similar results were obtained by Tuberoso et al. [18] who found $92.2 \mathrm{mg} \mathrm{GAE} / 100 \mathrm{~g}$ of strawberry tree honey. Slightly lower results were obtained by Beretta et al. [40] for Italian commercial strawberry tree honey (with $78.96 \mathrm{mg}$ of $\mathrm{GAE} / 100 \mathrm{~g}$ of honey). On the other hand, studies realized by Aazza et al. [20] and Alves et al. [16] with Portuguese honey samples (Arbutus unedo) showed slightly higher values; these were $117.6 \mathrm{mg}$ of GAE/100 $\mathrm{g}$ and $105.5 \mathrm{mg} \mathrm{GAE} / 100 \mathrm{~g}$, respectively. When compared with other unifloral honeys from the North of Portugal analyzed by Ferreira et al. [8], the results obtained for the phenolic content of rosemary (with $22.61 \mathrm{mg}$ of GAE/100 $\mathrm{g}$ of honey), viper's bugloss (with $40.62 \mathrm{mg}$ of GAE/100 g of honey), and heather (with $72.77 \mathrm{mg}$ of GAE/100 $\mathrm{g}$ of honey), the strawberry tree honey had significantly higher values $(P<0.05)$. Smaller mean values were also found for different unifloral honeys from Slovenia (chestnut, $19.99 \mathrm{mg}$ GAE/100 g; fir, $24.14 \mathrm{mg}$ GAE/100 g; spruce, $21.75 \mathrm{mg}$ GAE/100 g; and forest, $23.39 \mathrm{mg}$ GAE/100 g) and were found by Bertoncelj et al. [7]. Similarly, high phenolic contents were found by Silici et al. [41] for Rhododendron honeys that have shown mean values $121.6 \mathrm{mg}$ GAE/100 $\mathrm{g}$ of honey. This result clearly confirmed the claimed beneficial properties of the $A$. unedo honeys over other unifloral types of honey.

The variance values of phenolic content could be the consequence of the formation of compounds that could react as electron-donors, incrementing the real amount of phenol [8]. Folin-Ciocalteu's method is general for the estimation of the total phenolic content; other components such as peptides, vitamins C, E, carotenoids, sugars, amino acids, proteins, organic acids, or enzymes (glucose oxidase and catalase) can also influence the results but the components that influence more, by increasing the total phenolic value, are the product of Maillard reaction (melanoidins), since several researchers have demonstrated that those compounds presented an effect that is similar to a reducing agent (mixture of phosphotungstic acid and phosphomolybdic acid)
TABLE 2: Results for total phenolic content, total flavonoid content, DPPH scavenging radical, and antioxidant capacity of strawberry tree (Arbutus unedo) honey samples.

\begin{tabular}{lcc}
\hline Parameters & $\begin{array}{c}\text { Range } \\
{[\mathrm{min}-\mathrm{max}]}\end{array}$ & $x \pm \mathrm{SD}$ \\
\hline $\begin{array}{l}\text { Total phenolic content } \\
\text { (mg of GAE/100 g of honey) }\end{array}$ & $91.74-96.12$ & $94.47 \pm 2.37$ \\
$\begin{array}{l}\text { Total flavonoid content } \\
\text { (mg of QE/100 g of honey) }\end{array}$ & $4.09-5.77$ & $5.33 \pm 0.63$ \\
$\begin{array}{l}\text { DPPH scavenging (\%) } \\
\text { Antioxidant capacity }\end{array}$ & $40.28-45.20$ & $43.46 \pm 4.86$ \\
$\quad$ (mg of AEAC/100 g of honey) & $18.01-20.25$ & $18.85 \pm 0.12$ \\
$\quad$ (mg of QEAC/100 g of honey) & $9.64-10.78$ & $9.92 \pm 0.07$ \\
\hline
\end{tabular}

$[8,16,26]$. Honey is very prone to Maillard reactions during storage or when subjected to thermal processing. These occur when sugars condense with free amino acids leading to the formation of brown melanoidins [9].

Total flavonoid content (TFC) for strawberry tree honey was $5.33 \mathrm{mg}$ of QE/100 g of honey (Table 2). This value was lower than those found by Aazza et al. [20] who analyzed strawberry tree commercial honey showing a mean value of $9.66 \mathrm{mg}$ of QE/100 g. After analyzing honeys from different floral sources from Italy by Pichichero et al. [42], those honeys showed a range of flavonoid contents from $6.73 \mathrm{mg} \mathrm{QE} / 100 \mathrm{~g}$ of honey for acacia (Robinia pseudoacacia) to $21.16 \mathrm{mg}$ of $\mathrm{QE} / 100 \mathrm{~g}$ of honey for savory (Satureja hortensis). One kind of honey (sulla, Hedysarum spp.) showed the lowest total flavonoid value $4.18 \mathrm{mg}$ of $\mathrm{QE} / 100 \mathrm{~g}$ of honey. As for the strawberry tree samples, they showed similar results to those reported for lime honeys by $\mathrm{Al}$ et al. [43], whose samples showed ranges between 0.91 and $2.42 \mathrm{mg}$ of $\mathrm{QE} / 100 \mathrm{~g}$ of honey (for Acacia) and 4.70-6.98 mg of QE/100 g of honey (for Tilia). Similar results were also found for honeys from Burkina Faso; these samples showed ranges from 0.17 to $8.35 \mathrm{mg}$ of QE/100 g of honey [28]. In comparison with Portuguese honeys [8], rosemary (12.4 $\mathrm{mg}$ of catechin equivalents (CEs)/100 g of honey), viper's bugloss (34.3 $\mathrm{mg}$ of CEs/100 g of honey), and heather (58.7 mg of CEs/100 g of honey), strawberry tree honey TFC was significantly lower, considering that the analysis was performed with another standard (catechin). Flavonoids inhibit autooxidation reactions and have a scavenging effect on free radicals, by different mechanisms [44]. TFC was determined using a spectrophotometric method for the quantification of flavonoids with $\mathrm{AlCl}_{3}$, which is specific for flavones and flavonols [45], thus making our results very trustable.

Most phenolic compounds present in honey are in the form of flavonoids (e.g., quercetin, kaempferol, and pinocembrin) whose concentrations depend on various factors, including plant species used by bees, plant health, geographical origin, and climatic characteristics of the local production, where the floral origin is the major factor responsible for biological activity, including antioxidant and antimicrobial, because bioactive compounds of vegetal origin can be transferred to honey [42]. Several works on the phenolic fraction 
established homogentisic acid (2,5-dihydroxyphenylacetic acid; HGA) as a useful marker to assess botanical origin of strawberry tree honey $[4,18]$. It has been demonstrated that HGA is the most abundant phenolic compound in this type of honey, representing approximately $50-60 \%$ of total phenols which provides an important contribution to the high antioxidant and antiradical activities of strawberry tree honey $[4,10,12]$.

The strawberry tree honey obtained from the South of Portugal showed a mean value of DPPH scavenging of $43.46 \%$ (Table 2). Similar results were found by $\mathrm{Al}$ et al. [43] for acacia honey (from 35.8 to 45.3\%), lime honey (from 36.6 to $40.9 \%$ ), and sunflower honey (from 40.7 to $49.2 \%$ ). Slightly higher results were obtained by Silici et al. [41] for Rhododendron honey samples that showed mean values of $54.05 \%$ for DPPH scavenging activity. Alves et al. [16] found values of DPPH scavenging for Portuguese strawberry tree honey with a mean of $64.2 \%$. Rosa et al. [10] and Tuberoso et al. [4] found values of the scavenging ability on DPPH radicals for strawberry tree honeys produced in Italy with mean values of $4.8 \mathrm{mmol}$ trolox equivalent antioxidant capacity (TEAC) $/ \mathrm{kg}$ and $4.5 \mathrm{mmol} \mathrm{TEAC} / \mathrm{kg}$, respectively. Samples of the Portuguese honeys studied by Alves et al. [16] showed significant below than 50\% scavenging activity, where there were some samples of 4.5-59.3\% (rosemary), 8.8$23.2 \%$ (orange), $35.8-47.3 \%$ (thyme), and $27.7 \%$ (eucalyptus). The DPPH free radical has the advantage of being unaffected by certain side reactions, such as metal ion chelation and enzyme inhibition [41]. The higher the values of DPPH, the higher the antioxidant capacity of the honey samples. Several authors $[6,24]$ have established a direct relationship between antioxidant capacity of honey and the amount of bioactive compounds (e.g., phenolic and flavonoids) present, along with other compounds also involved [27, 40, 45].

The antioxidant capacity of strawberry tree honey showed values of $18.85 \mathrm{mg}$ ascorbic acid equivalent antioxidant content (AEAC)/100 of honey and $9.92 \mathrm{mg}$ of quercetin equivalent antioxidant content (QEAC)/100 g of honey (Table 2). These values were similar to those obtained by different researchers, for example, Meda et al. [28] for multifloral honey (4.27-17.30 mg of AEAC/100 $\mathrm{g}$ and $10.20-37.87 \mathrm{mg}$ of QEAC/100 g of honey), Saxena et al. [24] who found values between 15.1 and $29.5 \mathrm{mg}$ of AEAC/100 $\mathrm{g}$ of honey for Indian honeys, and Lachman et al. [39] for lime honey (16.3 mg AEAC/100 g), raspberry honey (20.6 mg AEAC/100 g), and rape honey (17.5 mg AEAC/100 g of honey). Many studies have demonstrated that honey serves as a source of natural antioxidants, which are effective in reducing the risk of heart diseases, cancer, immune-system decline, cataracts, different inflammatory process, and so forth. Among the mechanisms of action suggested are free radical sequestration, hydrogen donation, metallic ion chelation, and their ability to act as a substrate for radicals such as superoxide and hydroxyl [7, $41,42]$. The antioxidant activity of honey has been shown to strongly correlate with the content of phenolic and flavonoid compounds, but they are not solely responsible for this type of activity as there are other constituents such as vitamins, carotenoids, melanoidins, enzymes, organic acids, peptides, and possibly other minor compounds possessing antioxidant capacity $[7,10,44]$.

In general, it can be established that this kind of honey (strawberry tree) has the highest antioxidant activity, when compared with other kinds of honey samples (e.g., sulla, chestnut, chicory, dandelion, eucalyptus, citrus, and acacia) $[10,40]$. On the other hand, abbamele (a typical product originally from Sardinia island, obtained from the recuperation of this kind of honey from combs) has antioxidant activities comparable to those of well-known products such as red wines and vegetables; therefore the most bioactive compounds present in this product come directly from the original source Arbutus unedo honey [37].

\section{Conclusions}

This study can be possible to completely characterize several physicochemical parameters and biological activity of strawberry tree (Arbutus unedo L.) honey from South Portugal. The results showed that all physicochemical parameters were within limits established by International Regulations. There are slight differences between Portuguese and Italian honeys, considering that honey composition is highly dependent on weather and geographical and environmental conditions. Regarding biological activity, it is clearly shown that strawberry tree honey has better properties than most of the unifloral types of honey widely consumed in Portugal. This study can generate an interest in strawberry tree honey, from both consumers interested in its properties and exquisite flavor and producers, by producing honey of higher economic value and of extraordinary quality, instead of mixing strawberry tree honey with other inferior honey products.

\section{Conflict of Interests}

The authors declare that there is no conflict of interests regarding the publication of this paper.

\section{Acknowledgments}

The authors would like to thank Mr. Jose Chumbinho and beekeepers for providing strawberry tree honey samples. Pablo Ulloa was funded by Erasmus Mundus 2008-1022/002 European Program Frame ECW/17. This research was conducted in the premises of the Universidade do Algarve (Portugal).

\section{References}

[1] M. M. Özcan and H. Haciseferoğullari, "The Strawberry (Arbutus unedo L.) fruits: chemical composition, physical properties and mineral contents," Journal of Food Engineering, vol. 78, no. 3, pp. 1022-1028, 2007.

[2] G. Celikel, L. Demirsoy, and H. Demirsoy, "The strawberry tree (Arbutus unedo L.) selection in Turkey," Scientia Horticulturae, vol. 118, no. 2, pp. 115-119, 2008.

[3] A. Soro and R. J. Paxton, "The strawberry tree: a significant source of nectar around the Mediterranean basin," Bee World, vol. 80, no. 3, pp. 140-144, 1999. 
[4] C. I. G. Tuberoso, E. Bifulco, P. Caboni, F. Cottiglia, P. Cabras, and I. Floris, "Floral markers of strawberry tree (Arbutus unedo L.) honey," Journal of Agricultural and Food Chemistry, vol. 58, no. 1, pp. 384-389, 2010.

[5] I. Oliveira, P. Guedes De Pinho, R. Malheiro, P. Baptista, and J. A. Pereira, "Volatile profile of Arbutus unedo L. fruits through ripening stage," Food Chemistry, vol. 128, no. 3, pp. 667-673, 2011.

[6] A. M. Aljadi and M. Y. Kamaruddin, "Evaluation of the phenolic contents and antioxidant capacities of two Malaysian floral honeys," Food Chemistry, vol. 85, no. 4, pp. 513-518, 2004.

[7] J. Bertoncelj, U. Doberšek, M. Jamnik, and T. Golob, "Evaluation of the phenolic content, antioxidant activity and colour of Slovenian honey," Food Chemistry, vol. 105, no. 2, pp. 822-828, 2007.

[8] I. C. F. R. Ferreira, E. Aires, J. C. M. Barreira, and L. M. Estevinho, "Antioxidant activity of Portuguese honey samples: different contributions of the entire honey and phenolic extract," Food Chemistry, vol. 114, no. 4, pp. 1438-1443, 2009.

[9] K. Brudzynski and D. Miotto, "The relationship between the content of Maillard reaction-like products and bioactivity of Canadian honeys," Food Chemistry, vol. 124, no. 3, pp. 869-874, 2011.

[10] A. Rosa, C. I. G. Tuberoso, A. Atzeri, M. P. Melis, E. Bifulco, and M. A. Dessi, "Antioxidant profile of strawberry tree honey and its marker homogentisic acid in several models of oxidative stress," Food Chemistry, vol. 129, no. 3, pp. 1045-1053, 2011.

[11] L. Castro-Vázquez, M. C. Díaz-Maroto, C. de Torres, and M. S. Pérez-Coello, "Effect of geographical origin on the chemical and sensory characteristics of chestnut honeys," Food Research International, vol. 43, no. 10, pp. 2335-2340, 2010.

[12] P. Cabras, A. Angioni, C. Tuberoso et al., "Homogentisic acid: a phenolic acid as a marker of strawberry-tree (Arbutus unedo) honey," Journal of Agricultural and Food Chemistry, vol. 47, no. 10, pp. 4064-4067, 1999.

[13] F. Bianchi, M. Careri, and M. Musci, "Volatile norisoprenoids as markers of botanical origin of Sardinian strawberry-tree (Arbutus unedo L.) honey: characterisation of aroma compounds by dynamic headspace extraction and gas chromatography-mass spectrometry," Food Chemistry, vol. 89, no. 4, pp. 527-532, 2005.

[14] M. L. Felsner, C. B. Cano, R. E. Bruns, H. M. Watanabe, L. B. Almeida-Muradian, and J. R. Matos, "Characterization of monofloral honeys by ash contents through a hierarchical design," Journal of Food Composition and Analysis, vol. 17, no. 6, pp. 737-747, 2004.

[15] W. Von Der Ohe, L. Persano Oddo, M. L. Piana, M. Morlot, and P. Martin, "Harmonized methods of melissopalynology," Apidologie, vol. 35, supplement 1, pp. S18-S25, 2004.

[16] A. Alves, A. Ramos, M. M. Gonçalves, M. Bernardo, and B. Mendes, "Antioxidant activity, quality parameters and mineral content of Portuguese monofloral honeys," Journal of Food Composition and Analysis, vol. 30, no. 2, pp. 130-138, 2013.

[17] P. B. Andrade, M. T. Amaral, P. Isabel, J. C. M. F. Carvalho, R. M. Seabra, and A. Proença Da Cunha, "Physicochemical attributes and pollen spectrum of Portuguese heather honeys," Food Chemistry, vol. 66, no. 4, pp. 503-510, 1999.

[18] C. I. G. Tuberoso, I. Jerković, G. Sarais, F. Congiu, Z. Marijanović, and P. M. Kuś, "Color evaluation of seventeen European unifloral honey types by means of spectrophotometrically determined CIE $L^{*} C_{a b}^{*} h_{a b}^{\circ}$ chromaticity coordinates," Food Chemistry, vol. 145, pp. 284-291, 2014.
[19] N. Spano, L. Casula, A. Panzanelli et al., "An RP-HPLC determination of 5-hydroxymethylfurfural in honey: the case of strawberry tree honey," Talanta, vol. 68, no. 4, pp. 1390-1395, 2006.

[20] S. Aazza, B. Lyoussi, D. Antunes, and M. G. Miguel, "Physicochemical characterization and antioxidant activity of commercial portuguese honeys," Journal of Food Science, vol. 78, no. 8, pp. C1159-C1165, 2013.

[21] J. W. White, "Instrumental color classification of honey: collaborative study," Journal of the Association of Official Analytical Chemists, vol. 67, pp. 1129-1131, 1984.

[22] S. Bogdanov, International Honey Commission, Swiss Bee Research Centre, 2002.

[23] Codex Alimentarius Commission, Revised Codex Standard for Honey, Codex STAN 12-1981, Rev. 1, 1987, Rev. 2, 2001.

[24] S. Saxena, S. Gautam, and A. Sharma, "Physical, biochemical and antioxidant properties of some Indian honeys," Food Chemistry, vol. 118, no. 2, pp. 391-397, 2010.

[25] M. M. Özcan and Ç. Ölmez, "Some qualitative properties of different monofloral honeys," Food Chemistry, vol. 163, pp. 212$218,2014$.

[26] J. M. Alvarez-Suarez, S. Tulipani, S. Romandini, A. Vidal, and M. Battino, "Methodological aspects about determination of phenolic compounds and in vitro evaluation of antioxidant capacity in the honey: a review," Current Analytical Chemistry, vol. 5, no. 4, pp. 293-302, 2009.

[27] M. S. R. Flores, O. Escuredo, and M. C. Seijo, "Assessment of physicochemical and antioxidant characteristics of Quercus pyrenaica honeydew honeys," Food Chemistry, vol. 166, pp. 101106, 2015.

[28] A. Meda, C. E. Lamien, M. Romito, J. Millogo, and O. G. Nacoulma, "Determination of the total phenolic, flavonoid and proline contents in Burkina Fasan honey, as well as their radical scavenging activity," Food Chemistry, vol. 91, no. 3, pp. 571-577, 2005.

[29] L. Persano Oddo, L. Piana, S. Bogdanov et al., "Botanical species giving unifloral honey in Europe," Apidologie, vol. 35, supplement 1, pp. S82-S93, 2004.

[30] European Union Directive (EU), Council Directive 2001/110 Relating to Honey, Official Journal of the European Communities, 2001.

[31] L. P. Oddo, M. Piazza, A. Sabatini, and M. Accorti, "Characterization of unifloral honeys," Apidologie, vol. 26, no. 6, pp. 453465, 1995.

[32] V. Kaškoniene, P. R. Venskutonis, and V. Čeksteryte, "Carbohydrate composition and electrical conductivity of different origin honeys from Lithuania," LWT-Food Science and Technology, vol. 43, no. 5, pp. 801-807, 2010.

[33] X. Feás, J. Pires, A. Iglesias, and M. L. Estevinho, "Characterization of artisanal honey produced on the Northwest of Portugal by melissopalynological and physico-chemical data," Food and Chemical Toxicology, vol. 48, no. 12, pp. 3462-3470, 2010.

[34] S. Gomes, L. G. Dias, L. L. Moreira, P. Rodrigues, and L. Estevinho, "Physicochemical, microbiological and antimicrobial properties of commercial honeys from Portugal," Food and Chemical Toxicology, vol. 48, no. 2, pp. 544-548, 2010.

[35] L. R. Silva, R. Videira, A. P. Monteiro, P. Valentão, and P. B. Andrade, "Honey from Luso region (Portugal): physicochemical characteristics and mineral contents," Microchemical Journal, vol. 93, no. 1, pp. 73-77, 2009. 
[36] R. A. Gleiter, H. Horn, and H.-D. Isengard, "Influence of type and state of crystallisation on the water activity of honey," Food Chemistry, vol. 96, no. 3, pp. 441-445, 2006.

[37] I. Jerković, A. Kasum, Z. Marijanović, and C. I. G. Tuberoso, "Contribution to the characterisation of honey-based Sardinian product abbamele: volatile aroma composition, honey marker compounds and antioxidant activity," Food Chemistry, vol. 124, no. 1, pp. 401-410, 2011.

[38] S. Ajlouni and P. Sujirapinyokul, "Hydroxymethylfurfuraldehyde and amylase contents in Australian honey," Food Chemistry, vol. 119, no. 3, pp. 1000-1005, 2010.

[39] J. Lachman, M. Orsák, A. Hejtmánková, and E. Kovářová, “Evaluation of antioxidant activity and total phenolics of selected Czech honeys," LWT-Food Science and Technology, vol. 43, no. 1, pp. 52-58, 2010.

[40] G. Beretta, P. Granata, M. Ferrero, M. Orioli, and R. M. Facino, "Standardization of antioxidant properties of honey by a combination of spectrophotometric/fluorimetric assays and chemometrics," Analytica Chimica Acta, vol. 533, no. 2, pp. 185191, 2005.

[41] S. Silici, O. Sagdic, and L. Ekici, "Total phenolic content, antiradical, antioxidant and antimicrobial activities of Rhododendron honeys," Food Chemistry, vol. 121, no. 1, pp. 238-243, 2010.

[42] E. Pichichero, L. Canuti, and A. Canini, "Characterisation of the phenolic and flavonoid fractions and antioxidant power of Italian honeys of different botanical origin," Journal of the Science of Food and Agriculture, vol. 89, no. 4, pp. 609-616, 2009.

[43] M. L. Al, D. Daniel, A. Moise, O. Bobis, L. Laslo, and S. Bogdanov, "Physico-chemical and bioactive properties of different floral origin honeys from Romania," Food Chemistry, vol. 112, no. 4, pp. 863-867, 2009.

[44] M. I. Isla, A. Craig, R. Ordoñez et al., "Physico chemical and bioactive properties of honeys from Northwestern Argentina," LWT-Food Science and Technology, vol. 44, no. 9, pp. 19221930, 2011.

[45] C.-C. Chang, M.-H. Yang, H.-M. Wen, and J.-C. Chern, "Estimation of total flavonoid content in propolis by two complementary colometric methods," Journal of Food and Drug Analysis, vol. 10, no. 3, pp. 178-182, 2002. 